\title{
Otizm Spektrum Bozukluğu Olan Çocukların Geometrik Şekillerdeki Algı Seviyelerinin İncelenmesi
}

\author{
Erol Özçekiç ${ }^{*}$, Ediz Şaykol ${ }^{2}$ \\ ${ }^{1}$ Balıkesir Üniversitesi, Bigadiç Meslek Yüksekokulu, Balıkesir; \\ ${ }^{2}$ Beykent Üniversitesi, Bilgisayar Mühendisliği Bölümü, İstanbul
}

(Illk Geliş Tarihi 31 Ocak 2019 ve Kabul Tarihi 19 Nisan 2019)

(DOI: $10.31590 /$ ejosat.519509)

ATIF/REFERENCE: Özçekiç, E. \& Şaykol, E. (2019). Otizm Spektrum Bozukluğu Olan Çocukların Geometrik Şekillerdeki Algı Seviyelerinin İncelenmesi. Avrupa Bilim ve Teknoloji Dergisi, (16), 136-145.

$\ddot{O} \mathbf{z}$

$\mathrm{Bu}$ araştırmanın amacı otizmli öğrencilere verilen grafik dersleri yardımıyla algı düzeylerinin gözlem ve anket yöntemi etkinliği ile incelenmesidir. Bunun için mandala tekniği tercih edilmiş olup her öğrenciye birer mandala çizimi verilmiştir. Böylece grafiksel şekilleri tanıyıp tanımadığı, düzenli boyayıp boyayamadığı, nesneleri keşfedebilmesi, dikkat konuları üzerinde gözlem ve istatistiksel değerlendirme yapılacaktır. Araştırmada 100'e yakın denek kullanılması düşünülmektedir. Çalışmada yaşları 4-40 arasında değişen otizmli öğrenciler ile yaygın gelişimsel bozukluk gösteren otizmli öğrencilerle çalışılmıştır. Araştırmamızda haftanın 5 günü ve toplu, tekli ders oturumları ile öğretim, izleme ve etkinlik oturumları yapılmış, anlama, güvenirlik ve algı seviyesi verileri toplanmıştır. Verilerin çözümlenmesi esnasında SPSS analiz programından yararlanılmıştır. Araştırma bulguları deneklerin; "Geometrik şekil nedir?" kavram bilgisini \%85’ten fazla tam olarak kazandıkları ve elde edilen bu kazanımları, öğretim bittikten bir ay sonra bile olsa ortalama \%80 düzeyinde muhafaza ettikleri ve sınıf ortamı ile sosyal yaşamlarına bir katkı sağladıkları görülmüştür.

Anahtar kelimeler: Mandala öğretim tekniği, geometrik şekiller, otizm.

\section{Analysis of Children with Autism Spectrum Disorder With Perception Levels in Geometric Shapes}

\begin{abstract}
The aim of this study is to examine the perception levels with the help of the survey method by the help of the graphical lessons given to the students with autism. For this purpose, mandala technique is preferred and each student is given a mandala drawing. Thus, whether or not he recognizes the graphical shapes, he cannot paint regularly, he can discover the objects, observation and statistical evaluation will be made on the subjects of attention. Approximately 100 subjects are considered in the study. In this study, students with autism with ages ranging from 4 to 40 were studied. In our study, 5 days of the week and collective, single lecture sessions, training, monitoring and activity sessions were held, and data of comprehension, reliability and perception level were collected. SPSS analysis program was used to analyze the data. Research findings of the subjects; What is a geometric figure? they gained more than $85 \%$ of the concept knowledge, and these gains were maintained at an average of $80 \%$, even one month after the end of teaching, and contributed to their social lives through the classroom environment.
\end{abstract}

Key Words: Mandala instructional technique, geometric shapes, autism.

${ }^{2}$ Sorumlu Yazar: Beykent Üniversitesi, Mühendislik Mimarlık Fakültesi, Bilgisayar Mühendisliği Bölümü, İstanbul, ediz.saykol@,beykent.edu.tr 


\section{Giriş}

Tüm ebeveynlerin isteği annenin hamile olduğunu duyduktan sonra sağlıklı bir çocuğu dünyaya getirme arzusuna sahip olmaktır. Günümüzde en sık görülen engelli çocuklardan bir bölümünü de otizmli çocuklar oluşturmaktadır. Otizm genel itibariyle hayatın ilk safhalarında belirginlik gösteren ve varoldukça süregelen toplumsal diyalog, duygu, tutum ve zihinsel gelişimde yavaşlama ve sapma ile beliren duygu-düşünce durumu bozukluğudur. (Üstüner Top, 2009, Güleç-Aslan ve ark, 2009).

Özel gereksinime muhtaç fertler gibi, otizmli kişilerde sosyal yaşamın gerektirdiği çeşitli yeteneklere sahip olmak zorundadırlar. Kendine bakma, günlük hayat aktiviteleri, hesap yapmak, gezip dolaşmak, eğitim ve akademik kabiliyetin içinde bulunan okuma-yazma ile beraber bazı kolay aritmetik işlemlerin gündelik hayatda kullanımı şarttır. Bunların kazanımı ise, öğrenilip devam etmekte olan program ve eğitimlerin elemanlarından, gayelerin, kapsamın düzenlenmesine ve kapsama uyan teknik veya yaklaşımla sunumuna bağlıdır (Özyürek, 1990; Gürsel,1993). Otizmli çocuğun eğitimine başlanılacak nokta; çocuğun yapabileceği seviyedeki beceriler, elinin yatkın olduğu el becerileri ve acil günlük ihtiyaçlarını karşılayabileceği zorluk çeken beceriler olması gerekmektedir. Eğitim programı bir zincir halkası gibi bütündür. Yalnızca okulda çocuğun karşılaş̧ı̆̆ı problemler değil, dış dünyada ve evde meydana gelen tüm sorunlar öğretmen tarafından bir programa alınmalıdır.

Eğitim programlarındaki hedef ve konular dışında öğrencilerin kişisel özellikleri ve ihtiyaçlarına göre yeni hedef davranışlar da oluşturulabilir. Öğretmen bazen bireysel bazen de toplu öğrenci gruplarıyla çalışmalarını devam ettirmelidir.

Otistik çocukların herbirinin eğitsel gereksinimleri farklılık gösterebildiğinden dolayı eğitmenin hangi konuları gözönüne alarak nasıl hareket etmesi gerektiği hususunun iyi bilinmesi çok büyük önem taşımaktadır.

Otistik çocuklar kişisel farklılık gösterdiklerinden, performansları da birbirlerinden ayrıdır. Her çocuğun eğitim programına başlanmadan evvel öğrencinin gözlemlenmesi gereklidir. Çocukların becerisi ve performansı ölçüt bağımlı ölçü araçları ile tespit edilir. Performans ölçümü yapılırken otizmli öğrencilerden istediğimiz şey açıkça söylenir. Aldığımız sonuçlar tabloya kaydedilir (Güneş, 2013).

Ölçüt bağımlı ölçü araçlarıyla mevcut elimizde bulunan verilerle hedefler belirlenir, sonuca gitmede ara hedefler tespit edilir ve öğretim materyalleriyle bireysel veya toplu eğitim ortamlarında öğretime başlanır.

Ülkemizde otizmli çocuklara geometri öğretimi ve geometrik şekiller öğretim stratejilerinin araştırıldığı çalışmaların sayısı sınırlıdır. Bu sebepten dolayı yola çıkarak, bu araştırmada belirli süre içerisinde öğretim yöntemiyle sunulan grafik düzenleyicilerle otizmli öğrencilere geometrik şekiller bilgisi kavramları bilgisi verilmiş olup, yaşları ve eğitim seviyeleri farklı olan öğrencilerin geometrik şekilleri algılamaları farklıdır. Ayrıca cinsiyetleri farklı olan grupların geometriksel şekiller üzerinde yaptıkları boyama ve tak-çıkar uygulamaları da birbirİnden farklılık gösterir. Buna göre aşağıdaki hipotezler test edilmiştir.

H1: Öğrencilerin geometrik şekilleri algılama düzeyleri arasında yaşa göre farklılık vardır.

H2: Öğrencilerin geometrik şekilleri algıllama düzeyleri arasında eğitim seviyelerine göre farklılık vardır.

H3: Öğrencilerin geometrik şekilleri algılama düzeyleri arasında cinsiyetlerine göre farklılık vardır.

Belirttiğimiz bu hipotezlere cevap aramak için bir anket geliştirilmiştir. 100' e yakın denek ile başlangıçta çalışılması hedeflenmesine karşın elde edilen $\mathrm{N}=50$ örneklem sayısı verileri ile işlemleri tamamlayıp, analiz sonuçları aranmaya başlanmışıır.

\section{Yöntem}

Otizm tanısı konmuş çocuklara Mandala eğitim tekniği kullanılarak hem çocukların zinde kalması hem de geometrik şekillerin özelliklerinin algılanması sağlanmaktadır. Mandala, Sanskritçe "büyülü daire" anlamına gelen bir kelime olup, kırk bin yıl öncesine dayanan bir tarihe sahip olduğu söylenmektedir. Evreni, hayatı ve varoluşu şekillerle, geometrik figürlerle betimleyen bir bütündür (Berkmen,2009). Mandala desenleri orta bir merkezi noktada başlar, genellikle daire şeklinde olur ve merkezinden dışına doğru genişleyen bir düzene sahip yapılardan ibarettir. Mandalalar özellikle psiko analizciler tarafından çok incelenmiştir ve mandala çizmenin, boyamanın hatta bir mandalaya bakmanın kişinin ruh halini iyileştirdiği, kişiyi rahatlattığı ve eğittiği söylenmektedir.

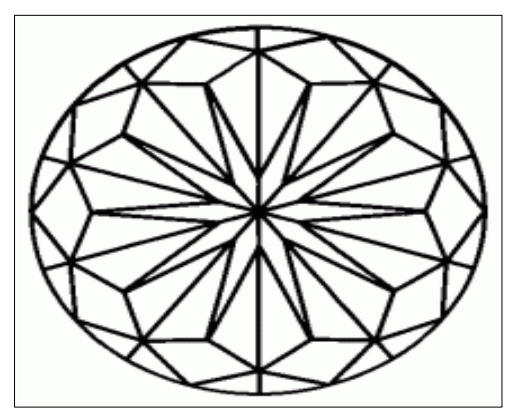




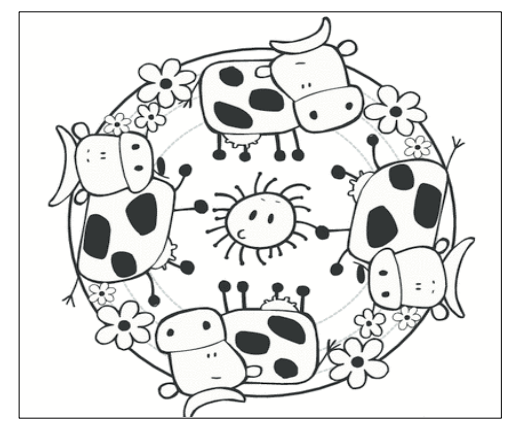

Şekil 1. Yaşlara göre değişen örnek Mandala desenleri

Desende yeralan figürlerin birbiriyle olan sözel ilişkisi, kişinin çevresi ile olan sosyal ahenk, interaktifliği hakkında bilgi sunmasının yanında aynı zamanda toplumun bireyi nasıl algıladığına dair de fikir vermektedir. Bilindiği gibi otistik çocuklar genellikle konuşmaktan kaçındıkları için mandala yöntemiyle kendilerini fikir, his ve davranışsal olarak çok daha iyi anlatabilirler. Mandala uygulamasında figürler basit - kolaydan, zor ve karmaşık olana doğru ilerlemelidir. Aynı zamanda bireylerin yaşlarına uygun figürler kullanılmadır. Mandala çizimi esnasında kullanılan pergel, cetvel, boya, kalem kalemleri çocukların ayrıca el kaslarının ve motor gelişimlerinin ilerlemesine de katkı sunmaktadır. Bunun yanısıra bu yöntem hiperaktif çocuklarda, Alzheimer hastalarında ve terapi tedavisinde günümüzde çokca tercih edilmektedir.

Son zamanlarda popüler olmasıyla birlikte mandala kitapları ve mandala eğitim kursları oldukça yaygınlaşmış durumdadır. Bu kadar fazla insanın ilgisini çekmeyi başaran mandalalar, içerisinde çok farklı potansiyeller barındırmaktadır. Bunlardan biri de matematikteki simetri konularından olan yansıma ve dönme simetrileri ile grafiksel şekillerin öğretimidir.

Eğitimde mandalanın kullanımı okul öncesi seviyeden yüksek öğretim seviyesine kadar her seviyede yapılabilme imkanına sahiptir. Okul öncesi dönemde mandala desenlerinin boyanmasıyla, odaklanılmış bir hedef de olabilir, örneğin yuvarlak şekilleri aynı renge boyayın vb. gibi, ilkokul seviyesinde eş parçalara katlama etkinlikleri ve eş şekilleri boyama etkinlikleri ile ve orta öğretim seviyesinde ise simetri konuları ile ilişkilendirilmesi için farklı mandala desenlerinin incelenmesini içeren çalışmalarla öğretim materyali olarak da kullanılabilir. İçerisinde hayvan desenlerinin yer aldığı tek simetri eksenli mandalalardan, renklendirilmiş mandala desenlerinin incelenmesine ve çizilmiş mandalaların boyanmasına birçok etkinlik farklı amaçlar için kullanılabilir. Otizmli öğrencilerle yapılmış bir çalışma, örnek bir öğrenme ortamı sunabilir.

Mandalanın çiziminde kağıt, kalem, cetvel ve pergel gibi malzemelerin kullanılmasıyla, mandala çizimlerinin yapılmasında matematik konuları da işe koşulabilir. Böyle çizimlerin yapılması çember-daire konularında ise ayrı bir öneme sahip olacaktır. Belli bir yarıçap uzunluğuna sahip dairelerin içerisine istenen sayıda simetri eksenine sahip desenlerin oluşturulması ise öğrencilerin öğrendikleri bilgileri kullanmasını sağlayacak bir ortam gerçekleştirilebilir. Mandala çizimlerini yapmakta ve etkinliklerde kullanabileceğiniz mandalaları ayarlamakta yardımcı olacak bir tablet bilgisayar uygulaması da kullanabiliriz. Bu tarzda yapılacak çalışmalar öğrencilerin öğrenme motivasyonlarını artıracak ve matematik ile sanat arasındaki ilişkiyi, geometrik şekillerle nesneler arasında bağlantı kurmalarında yardımcı olacaktır. Ayrıca, mandala ile yapılan çalışmaların kişinin konsantrasyon becerisini artırdığı, kişinin kendini tanımasını sağladı̆̆ı, kişiyi sakinleştirdiği ve yaratıcı düşünmesini sağladığı söylenmektedir. Yani öğrencilerin davranışlarını düzeltmelerinde ve kendilerini geliştirmelerinde bir araç olarak kullanılabilecektir.

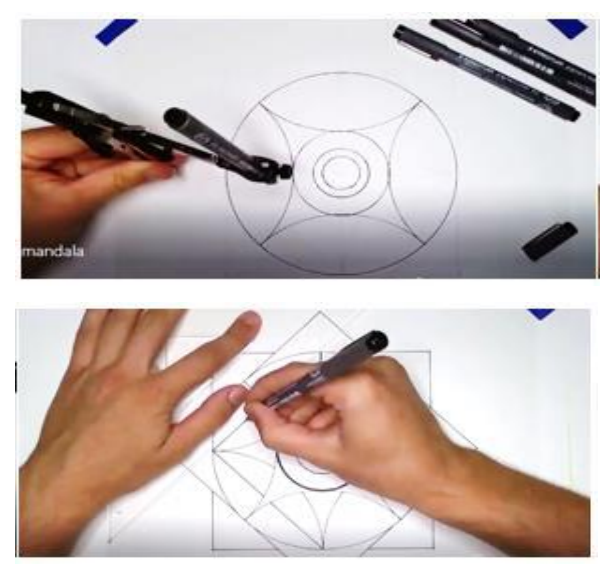

Şekil 2.Mandala deseninin oluşturulmasında pergel ve cetvel kullanımı 
Mandala belirgin bir figürde sabit duran merkez noktası etrafına şekiller ve figürler yerleştirilerek hazırlanmış geometrik şekillerden oluşan ve basitten zora doğru sıralanmış on çalışma kağıdından oluşmaktadır. Çalışmada öğretmenimiz öğrencisine her bir oturumda yapması gerekenleri söylemiş ve "önündeki şekile dikkatlice bakıp konsantre olduktan sonra, kare olanları sırayla en dıştan içe doğru boya" yönergesini vermiştir. Boyama bittikten sonra çalışma hakkında çocukla, "Kaç tane kare var?, Hangileri büyük,küçük?,Hangileri gizlenmiş?, Boyanmamış başka kare var mı?”, Şekli düzgün ve dışına taşırmadan boyama işlemini tamamlayabildin mi? gibi sorular sorularak biraz sohbet edilmişstir. Öğrencilerin dikkat, konsantrasyon, sayı ve süre ile ilgili ölçümleri gözlemlenip, değerlendirilmiştir. Çalışmada her biri farklı geometriksel desenli mandala figürleri mevcut olup, tekrarlı bir yol izlenmiştir ve totalde beş oturum olarak yapılmıştır. Uygulamalarda çocuklarla teker ilgilenilmiştir. Ortalama süre (boyama, bulma, sayma gibi faktörler için) her bir çalışmada $10 \mathrm{dk}$. olarak belirlenmiştir.

Mandalanın yararları hakkında aşağıdaki maddeler söylenebilir (Yıldırım, S., Akman, B. \& Alabay, E. 2012).

- Çocukların stresini azaltır. Ruhsal rahatlık, kendini motive etme ve dinginlik sağlar.

- Seçim yapmayı kolaylaştırır.

- Grup içi ve gruplar arası adaptasyonu artırır.

- Hoşgörü ve sabrı öğretir.

- Odaklanma süresi ve sürdürebilme yeteneğini geliştirir.

- Beyin sağ lob gelişiminin artmasına yardımcı olur. (Renkli çizimler sağ lobu aktifleştirerek duyguların anlam kazanmasında etkilidir)

- El ve gözün birlikte çalışımını ve ince motor gelişimini destekler.

- Yaratıcılik artar.

\subsection{Araştırmaya Katılan Öğrenciler}

Araştırmanın evrenini Balıkesir ili Altıeylül ilçesinde yer alan özel eğitim ve rehabilitasyon kurumundaki öğrenciler ve öğretmenler oluşturmaktadır.

Araştırmanın örneklem grubu ise Balıkesir ili Altıeylül ilçesinde yer alan Özel Eğitim ve Rehabilitasyon Merkezi’ndeki otizmli çocuklara eğitim veren ve yansız olarak seçilen 5 öğretmenden oluşmaktadır.

Araştırmaya şu öğrenciler alınmıştır:

1- Tek eylem gerektiren yönergeleri yerine getirir.

2- Görsel uyaran içeren televizyon, projeksiyon gösterisi, video görüntüleme vb. araçları izler.

3- Gösterilen hareketleri taklit eder.

4- Nesnelerle 1'den 10'a kadar sayar. (Gülsöz, T., Çıkılı, Y. , 2018)

\section{2. Öğretim Programlarının Hazırlanması}

Uygulama öncesinde araştırmaya katılacak öğrenci seçimi, programların hazırlanması, materyal temini ve ortam düzenlemeleri yapılmıştır. Ayrıca araştırmaya katılacak öğrencilerin başlama düzeyleri belirlenmiştir. Araştırmaya katılacak öğrenciler otizm tanısı ve yaygın gelişimsel bozukluk gösteren bir ilkokul-ortaokul-lise bünyesinde eğitimine devam etmesi gerekirken eğitimi özel rehabilitasyon merkezinde devam eden öğrencilerden seçilmiştir.

\subsection{Veri Toplama Aracı}

İyileştirilmesi hedeflenen amaçlar doğrultusunda verilerin toplanmasında 10 değişik karakteristik otistik davranış gösteren öğrencilerin Mandala çizim kağıtlarını boyama ve desenleri tanıyıp tanıyamadıkları gopro hero+3 action kamera yardımı ile kayıt altına alınmış olup ayrıca 18 sorudan oluşan anket yapılıp değerlendirmeleri sonuçlandırılmıştır.

\subsection{Verilerin Analizi}

Statistical Package for Social Sciences SPSS programı ile analizleri yapılmıştır. Deneklerin test sonuçları KMO ve Bartlett Testi güvenilirlik testi Cronbach Alpha katsayısı kullanılarak değerlendirilmiştir

Geçerlik analizleri; madde analizi, bir ölçme aracının tamamında - alt boyutlara ait bölümlerde yeralan itemların tamamında veya boyutlara ait bölümlerde istatistiksel anlamlılığı değerlendirmeyi amaçlar (Otrar, 2012; Gülten, 2012; Özkan, 2015; Argın, 2015). Faktör analizi yorumu zor olan birçok birbiriyle bağlantılı değişkeni, faktör adı altında görece olarak bağımsız yapılar altında birleştiren çok değişkenli istatistiksel bir yöntemdir (Büyüköztürk, 2002; Köymen, 1994; Tekin, 1993; Tezbaşaran, 1996; Turgut, 1997; Yıldırım, 1999). Bu analiz aynı şekilde yapı geçerliliği analizi olarak da bilinmektedir (Köymen, 1994). Çalışmada faktör yapısını belirlemek için temel bileşenler (TBA) analizi uygulanmıştır 


\section{European Journal of Science and Technology}

(Principal Component Analysis - PCA). Tespit edilen bileşenlerin yorumlanmasını kolaylaştırmak amacıyla genellikle en çok tercih edilen ortagonal döndürme yöntemi olan Varimax kullanılmıştır (Otrar, 2012; Çağırgan Gülten, 2012; Özkan, 2012; Argın, 2015). Fakat bundan önce veri setinin temel bileşenler analizine uygunluğunu belirlemek amacıyla KaiserMeyer-Olkin (KMO) ve Barlett Küresellik Testi uygulanmıştır. KMO değeri 0' la 1 arasında değer alan bir testtir, 1'e yakın olması veri setinin faktör analizine uygunluğunun artmasını gösterir. Aşağıdaki Tablo 1'de KMO değerleri ve açıklaması yer almaktadır (Semerci, 2004).

Tablo 1: KMO Derecelendirme Tablosu

\begin{tabular}{|l|l|}
\hline \multicolumn{1}{|c|}{ KMO Değeri } & \multicolumn{1}{c|}{ Açıklama } \\
\hline $1,00 \leq \mathrm{KMO} \leq 0,90$ & Mükemmel \\
\hline $0,90<\mathrm{KMO} \leq 0,80$ & İyi \\
\hline $0,80<\mathrm{KMO} \leq 0,70$ & Orta Düzey \\
\hline $0,70<\mathrm{KMO} \leq 0,60$ & Zayıf \\
\hline $0,60<\mathrm{KMO}$ & Kötü \\
\hline
\end{tabular}

Güvenilirlik Analizleri; Güvenilirlik bir ölçeğin ölçtüğü kavramı veya yapıyı ne kadar doğru ölçmesi ile ilişkilidir (Tekin, 1993). Likert tipi ölçeklerde güvenilirliği ölçmek için genellikle Cronbach Alpha kullanılır. Alfa değeri uygulanan ölçeğin iç tutarlılığını gösterir (Tekin, 1993; Tezbaşaran, 1996; Turgut, 1997; Yıldırım, 1999). Güvenirliliği ölçmek için iki hafta arayla test - retest yöntemi uygulanmıştır. Tüm analizler SPSS 22.0 (Statistical Package for the Social Sciences) programı yardımıyla yapılmıştır (Otrar, 2012; Gülten, 2012; Özkan, 2015; Argın, 2015).

\section{4. Öğretim Programının Uygulanması}

Uygulama öncesinde araştırmaya katılacak öğrenci seçimi, programların hazırlanması, materyal temini ve ortam düzenlemeleri sınıfta ve masada yapılmıştır. Ayrıca araştırmaya katılacak öğrencilerin başlama düzeyleri belirlenmiştir. Araştırmaya katılacak öğrenciler otizm ve yaygın gelişimsel bozukluk tanısı almış olan, bir ilkokul-ortaokul-lise eğitimine devam etmesi gerekip, edemeyen ve özel eğitim alan öğrencilerden seçilmiştir. Kullanılacak yöntem ve hedeflenen beceriler doğrultusunda öğretim oturumlarını gerçekleştirmek için araştırmacı tarafından öğretim planları, bir yetişkinin sadece beceriyi gerçekleştirme açısının odaklandığı video kayıtları ve öğretim esnasında çizimde ve boyama aşamasında kullanılan diğer (Mandala resimleri, tak-çıkar oyuncakları, geometrik figürleri yerleştirme ekipmanları vb.) malzemeler temin edilmiştir.

Uygulama sürecinde Öğretim oturumları hazırlanan öğretim programları doğrultusunda gerçekleştirilmiştir. Geometrik cisimleri tanıyabilme becerisi; kalem kullanımı, grafiksel şekli seçebilme, algılayabilme, düzenli boyayabilme şeklinde alt basamaklar oluşturularak gerçekleştirilmiştir. Özel Eğitim Uygulama Merkezi’nin uygulamalar için hazırlanan sınıfına öğrenci ile birlikte geçilmiştir. Öğretim için hazırlanan boyanacak kartlar ile öğrencinin dikkati çekilerek, resimler üzerine konuşuldu. Üçgen resmi gösterilerek “Üçgen çizmek ister misin?” sorusuna öğrenciden alınan cevabın ardından "Şimdi seninle üçgen yapmayı öğreneceğiz." diyerek uygulamaya geçiş yapıldı. Öğrencilerin herbirine telefondan bir eğitim videosu açılıp izletme işi yaptırıldı. Daha sonra izleme başarılı şekilde sonuçlandıysa eğer öğrenci ödüllendirildi. Bu işlemin ardından öğrenciden video da izlediklerini yapması istenmiştir. Bunun içinde 1'den 5'e kadar başarısını belirten bir puanlama sistemi kullanılmıştır.

\section{5. İzleme}

İzleme oturumları, katılımcının öğrendiği davranışları öğretim sonrası değerlendirme oturumlarından haftalarda gerçekleştirip gerçekleştiremediğini görmek amacıyla yapılmıştır. İzleme oturumları başlama düzeyi oturumları gibi gerçekleştirilmiştir. Öğrencilere sınıf ortamında video kayıt izlettirmeden sadece sözel olarak beceri yönergesi ile söylenen işlemleri yapması istenmiştir.

\subsection{Uygulama Güvenirliği}

Uygulama güvenirliği verilerinin toplanmasında kullanılmak üzere Becerilerinin Video Modelle Öğretim Etkinlikleri Uygulama Güvenirliği Formu hazırlanmıştır. Uygulama güvenirliğinin belirlenmesi amacıyla uygulamanın yapıldığı eğitim merkezinde görev yapan bir özel eğitim öğretmeninden katılımcı gözlemci yardımı alınmıştır. Katılımcı

gözlemciye bu formun kullanımı ve yürütülen program hususunda bilgi verilmiştir. Katılımcı gözlemci uygulama süresince araştırmacının yapması gereken ve yapması gerekip de yapmadığı davranışları forma kayıt etmiştir. 


\section{Bulgular}

Ölçeğin yapı geçerliliğini belirlemek amacıyla veriler üzerinde ilk olarak Kaiser-Meyer-Oklin (KMO) ve Bartlett test analizleri yapılmış ve $\mathrm{KMO}=0.897$; Bartlett testi değeri ise $\mathrm{x}^{2}=930,805 ;(\mathrm{p}=0.000)$ olarak belirlenmiştir. Davranış bilimlerinde KMO değerinin 0.60 'dan yüksek olması faktör analizi yapılabilmesi için yeterli görüldüğ̆̈̈nden dolayı (Büyüköztük. 2002; Tavşancıl, 2010), 15 maddelik ölçek üzerinde faktör analizi yapılabileceği anlaşılmıştır. Ölçeğin boyutlarını belirlemek üzere temel bileşenler analizi yapılmıştır. Ölçeğin birbirinden bağımsız faktörlere ayrışıp ayrışmadığını belirlemek amacıyla ise Varimax dik döndürme tekniği uygulanmıştır. Faktör analizlerinde yük değeri, bir maddenin tanımlanacak olan bir alt boyutta (faktörde) yer alıp almadığını ve böylece söz konusu faktörle olan ilişkisini gösterir. Belli bir grup madde bir faktörün altında yüksek yük değeri ile bulunuyorsa, bu maddeler ilgili faktörü tanımlayan/ölçen maddeler olarak yorumlanırlar. Genellikle bir maddenin yük değerinin 0.45 ve daha yüksek olması beklenir. Bu çalışmada yük değerleri 0.50' nin üzerinde olanlar alınmıştır. Bu alanda Temel Bileşenler Analizi yöntemine pek çok kaynakta rastlanmaktadır (Klainbaum, Kupper ve Muller, 1987; Zeller ve Karmines, 1978). Ölçeğin amacı süre ve sayıları ölçmek olduğu için program iki faktöre zorlanarak analiz tekrarlanmış ve sonuçlar aşağıda özetlenmiştir.

Bu teknikle yapılan açıklayıcı faktör analizinde, özdeğeri 1'in üstünde olan iki faktör toplam varyansın \%70.36'sını açıklamaktadır. Ölçme araçının faktör yapısı Tablo 6'da verilmiştir. Sonra Varimax Yöntemi kullanılmış ve faktör dağılımı daha açık hale getirilmiştir. Bazı maddelerin birden çok faktöre yayıldığı $(<0,30)$ görülmüşsür. Bu binişik olan 3 madde sırasıyla ölçekten çıkartılarak (Buyukozturk, 2012) analiz tekrar edilmiş ve kalan 15 Madde üzerinden analizler yapılmıştır. Bu aşamada açıklanana toplam varyans 2 bileşende $\% 70.366$ dır.

Faktörlerin açıkladıkları varyans miktarları ise sırasıyla birinci faktör için \%24.471, ikinci faktör için \%13.355, olarak belirlenmiştir. Faktör analizi sonunda elde edilen varyans oranları ne kadar yüksek olursa, ölçeğin faktör yapısı da o kadar güçlü olmaktadır. Sosyal bilimlerde çok yüksek varyans oranlarına ulaşmak mümkün olmamakta, \%40 ile \%60 arasında değişen varyans oranları yeterli kabul edilmektedir (Tavşancıl, 2010). Maddelerin faktörlere dağılımını belirlemek için yapılan Varimax dik döndürme analizi sonuçları ise aşağıdaki tabloda sunulmuştur. Tablo da görüldüğü üzere birinci faktör 8 maddeden $(11,13,14,15,16,17,18$, 19. maddeler); ikinci faktör 7 maddeden $(1,3,4,5,6,7,12$. maddeler) oluşmaktadır. Her bir faktör içine giren maddeler incelenerek oluşan alt boyutlar isimlendirilmiştir. Bu bağlamda birinci alt boyut sayı alt boyutu olarak; ikinci alt boyut süre alt boyutu olarak; isimlendirilmesi uygun görülmüştür.

Ölçeğin güvenilirliğini ölçmek için Cronbach $\alpha$ kullanılmış ve tum olceğin iç tutarlık katsayısı Cronbach $\alpha=.933$ olarak hesaplanmıştır. Cronbach's Alpha değerlerine bakıldığında hepsinin $0,90^{\prime}$ nın üzerinde olması veri setinin güvenilirliğini onaylamaktadır. Maddelere İlişkin Yığılma Grafiği Şekil 3’te verilmiş̧tir.

Tablo 2: Ölçeğin Faktör Yapısı

\begin{tabular}{l|c}
\hline \multicolumn{1}{c}{ Sayı } & \multicolumn{1}{c}{ Süre } \\
\hline $\begin{array}{l}\text { 1. Söylenen Geometrik Şekillerden Bulunan } \\
\text { Geometrik Şekil Sayısı }\end{array}$ &, 906 \\
\hline $\begin{array}{l}\text { 2. Verilen Geometrik Şekillerden } \\
\text { Söylenen Geometrik Şekil Sayısı }\end{array}$ &, 889 \\
\hline $\begin{array}{l}\text { 3.Karmaşık Geometrik Şekiller Arasından } \\
\text { Bulunan Geometrik Şekil Sayısı }\end{array}$ &, 786 \\
\hline $\begin{array}{l}\text { 4.Verilen Geometrik Şekillerden Gösterilen } \\
\text { Şeklin Hangi Renk Olduğunu Söyleme }\end{array}$ &, 760 \\
\hline $\begin{array}{l}\text { 5.Gizli Nesne Resimleri Arasından } \\
\text { Bulunan Gizli Nesne Resmi Sayısı }\end{array}$ &, 716 \\
\hline $\begin{array}{l}\text { 6.Verilen Geometrik Şekillerden Başarılı } \\
\text { Örüntü Oluşturma Sayısı }\end{array}$ &, 672 \\
\hline $\begin{array}{l}\text { 7.El Göz Koordinasyonu Gerektiren } \\
\text { Görevi Tamamlama Sayısı }\end{array}$ &, 591 \\
\hline $\begin{array}{l}\text { 8.Verilen Geometrik Şekillerle } \\
\text { Tak Çıkar Yapma Sayısı }\end{array}$ &, 542 \\
\hline \begin{tabular}{l} 
1.Aktiviteye Katılım \\
\hline
\end{tabular}
\end{tabular}


European Journal of Science and Technology

\begin{tabular}{|c|c|c|}
\hline Süresi & & \\
\hline $\begin{array}{l}\text { 2.Uzman Gözetimsiz Oturarak } \\
\text { Bekleme Süresi }\end{array}$ & & ,796 \\
\hline $\begin{array}{l}\text { 3.Görev Tamamlama } \\
\text { Sayıs1 }\end{array}$ & & ,791 \\
\hline $\begin{array}{l}\text { 4.Uzman Gözetiminde Oturarak } \\
\text { Bekleme Süresi }\end{array}$ & & ,762 \\
\hline 5.Dikkat Süresi & & ,727 \\
\hline $\begin{array}{l}\text { 6.Konsantrasyon } \\
\text { Süresi }\end{array}$ & & 687, \\
\hline $\begin{array}{l}\text { 7.Göz Kontağ } \\
\text { Süresi }\end{array}$ & & 664 \\
\hline Özdeger & 8,95 & 1,60 \\
\hline$\%$ Varyans & 59,70 & 10,67 \\
\hline Cronbach Alpha (a) .94 & .92 & .91 \\
\hline
\end{tabular}

Çalışmada ortalamalar arasındaki farklara bakarak analizler yapabilmemiz icin faktörler ile değişkenlerin dağılımları ve verilerin homojenliği test edilmiştir. Dağılımın normal bir dağılım olma durumu icin explore kullanılmıştır.

Varyanslerın homojenliği kontrol edildiğinde $p>0,05$ olduğu görülmüsştür. Buda dağılımın homojen bir dağılım olduğunu bize göstermiştir.

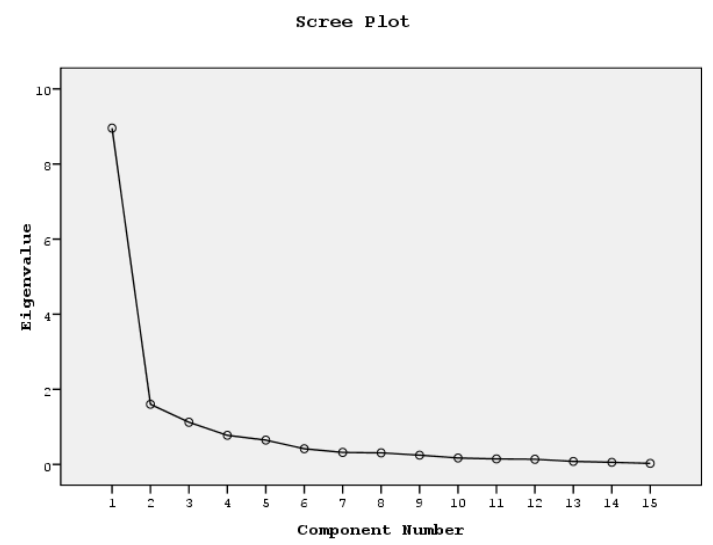

Şekil 3: Data Setindeki Maddelere İlişkin Yı̆̆glma Grafĭği

Ölçeğimizi oluşturan 15 adet sorunun grafiği yukarıdaki gibi verilmiştir. 1'den itibaren 15' e giderken kuvvetin azaldığı görülmektedir.

Bir faktör analizinde tüm faktörler kullanılmaz Eigen değerleri büyük olan faktörler kullanılmalıdır. Şekil 3'de görüldüğü gibi az sayıda faktörün eigen değeri yüksek olur. Buda faktör seçiminde kullanılan yöntemlerdendir.

\subsection{Cinsiyet İle Boyutların Analizi}

Çalışmaya katılan katılımcıların performans sayı ve süreleri ile, cinsiyetleri, eğitim durumları, ve yaşları arasındaki ilişkiyi belirlemek amacıyla bağımsız örneklem $t$ testi ile karşılaştırılmıştır. İlk olarak, kız ve erkeklerin ölçekten aldıkları puanlar arasındaki farkları belirlemek amacıyla bağımsız örneklemli t testi uygulanmış ve sonuçlar Tablo 3'de gösterilmiştir

Sonuçlar, ölçeğin "süre ve sayı" boyutunda kız ve erkek öğrenciler arasında istatistiksel olarak anlamlı fark olmadığını göstermiştir ( $\mathrm{t}_{48}=-1,30 ; \mathrm{p}>0,05$ ve $\left.\mathrm{t} 48=-1,54 ; \mathrm{p}>0,05\right)$. Bu sonuç, otizimli öğrencilerin cinsiyetleri ile süre ve sayı performans düzeyleri arasında istatistiksel olarak anlamlı bir fark olmadığı saptanmıştır.

Tablo 3. Kız ve erkek ögrencilerin ölçekten aldıkları puanların karşılaştırılması 


\begin{tabular}{|c|c|c|c|c|c|c|c|c|}
\hline & \multicolumn{3}{|c|}{ Kız } & \multicolumn{3}{|c|}{ Erkek } & & \\
\hline & $\mathbf{N}$ & $\mathbf{x}$ & SS & $\mathbf{N}$ & $\mathbf{x}$ & SS & $\mathbf{t}$ & $\mathbf{p}$ \\
\hline Sayı & 14 & 2,87 & 0,95 & 36 & 2,45 & 1,18 & $-1,30$ & 0,210 \\
\hline Süre & 14 & 3,28 & 0,82 & 36 & 2,86 & 0,98 & $-1,54$ & 0,142 \\
\hline
\end{tabular}

\subsection{Yaş İle Boyutların Analizi}

Katılımcıların yaşları ile ölçeğin boyutları arasındaki ilişkiyi tespit etmek amaçı ile bağımsız örneklem $t$ testi kullanılmıştır. Katılımcıların yaşları 18 yaş altı ve 18 yaş üstü olarak ikiye ayrılmıştır. Bağımsız örneklemli t testi uygulanmış ve sonuçlar Tablo 4'te gösterilmiştir.

Tablo 4. 18 yaş altı ve 18 yaş üstü ögrencilerin ölçekten aldıkları puanların karşılaştırılması

\begin{tabular}{|c|c|c|c|c|c|c|c|c|}
\hline & \multicolumn{3}{|c|}{18 Yaş Altı } & \multicolumn{3}{|c|}{18 Yaş Üstü } & & \\
\hline & $\mathbf{N}$ & $\mathbf{x}$ & SS & $\mathbf{N}$ & $\mathbf{x}$ & SS & $\mathbf{t}$ & $\mathbf{p}$ \\
\hline Sayı & 38 & 2,52 & 1,18 & 12 & 2,73 & 0,95 & $-0,64$ & 0,531 \\
\hline Süre & 38 & 2,85 & 0,99 & 12 & 3,38 & 0,69 & $-2,11$ & 0,045 \\
\hline
\end{tabular}

Bu sonuçlar, ölçeğin sayı boyutunda öğrencilerin 18 yaşından büyük yada küçük olması ile arasında istatistiksel olarak anlamlı fark olmadığını göstermiştir $\left(\mathrm{t}_{48}=-0,64 ; \mathrm{p}>0,05\right)$.

Bu sonucun yanında yaşın 18 yaş üstü olmasının süre olarak anlamlı farkın olduğunu göstermiştir $(\mathrm{t}$ 48= $-2,11$; $\mathrm{p}<$ $0,05)$.

Bu sonuç ile otizimli öğrencilerin 18 yaştan büyük olanların süre performans düzeyleri arasında istatistiksel olarak anlamlı bir fark vardır. Bu farkta yaşı büyük olanlar küçük olanlara göre süreyi kullanmada daha başarılı oldukları görülmüştür.

\subsection{Eğitim İle Boyutların Analizi}

Otizmli katılımcı öğrencilerin eğitim durumları ile boyutlar arasındaki ilişki test edildiğinde 0-4 yıl ile 5-9 yıl eğitim almışlar ile "sayı ve süre" arasında istatistiksel olarak anlamlı fark olmadığı görülmüştür $\left(\mathrm{t}_{48}=-1,44 ; \mathrm{p}>0,05\right.$ ve t ${ }_{48}=-$ $1,13 ; \mathrm{p}>0,05)$.

Sonuçlar Tablo 5'te verilmiştir. Bu sonuç, otizimli öğrencilerin cinsiyetleri ile süre ve sayı performans düzeyleri arasında istatistiksel olarak anlamlı bir fark olmadığı saptanmıştır.

Sonuç olarak öğrencilerin okulda almış oldukları eğitimin süresi ile boyutlar olan sayı ve süre arasında bir ilişki yoktur.

Tablo 5. 0-4 yll ve 5-9 yıl eğitim alan öğrencilerin ölçekten aldıkları puanların karşılaştırllması

\begin{tabular}{|c|c|c|c|c|c|c|c|c|}
\hline & \multicolumn{3}{|c|}{ 0-4 Yil } & \multicolumn{3}{|c|}{ 5-9 Yil } & & \\
\hline & $\mathbf{N}$ & $\mathbf{x}$ & SS & $\mathbf{N}$ & $\mathbf{x}$ & SS & $\mathbf{t}$ & $\mathbf{p}$ \\
\hline Sayı & 31 & 2,39 & 1,12 & 19 & 2,86 & 1,09 & $-1,44$ & 0,160 \\
\hline Süre & 31 & 2,86 & 0,95 & 19 & 3,17 & 0,93 & $-1,13$ & 0,272 \\
\hline
\end{tabular}

\section{Sonuç ve Öneriler}

$\mathrm{Bu}$ araştırmada öğrencilerin geometrik şekillere ilişkin bilgilerini ölçmek amacıyla 10 uzmanın görüşü alınarak bir anket düzenlenmiştir. 18 sorudan oluşan bir bilgi ölçme anketi hazırlanmıştır. Bunların dışında tum olceğin ve alt boyutlarının guvenirlik katsayıları (Cronbach $\alpha$ ), faktor bazında ayırt edicilik işlemleri, güvenilirlik analizleri katsayısı hesaplamaları yapılmıştır. 
$\mathrm{Bu}$ analizlere bağlı olarak varılan sonuclar aşağıda verilmiştir:

- Yapılan anketteki eigen değeri ölçütüne göre önemli iki faktorun acıkladığı toplam varyans \%70.00'dir. Varimax rotasyon sonucunda maddelerin faktör yükleri 0.536 - 0.906 arasında değişmektedir. Belirlenen faktörler sırasıyla "sayı" ve "süre" olarak adlandırılmıştır.

- Ölceğin tumu icin cronbach $\alpha \mathrm{T}=0.945$ ve her bir alt boyut icin hesaplanan cronbach $\alpha$ katsayılarının 0.70 'in uzerinde olması olceğin butun olarak ve alt boyutlarının kendi icinde tutarlı olduklarına işaret etmektedir.

- Faktor bazında analizlerde ayırt edicilik istatistiksel olarak tüm gruplar kapsamında anlamlı bulunmuştur $(p<.001)$.

- Faktörler olarak aldığımız "sayı ve süre" ile yaş, eğitim ve cinsiyet ilişkileri belirlemek icin yapılan analizlerin sonucunda 18 yaş üstü otizmli öğrencilerin sürelerini kullanmada daha etkili oldukları tespit edilmiştir.

Diğerlerinde anlamlı bir ilişki bulunmamıştır.

Yapılan tüm bu geçerlik ve güvenirlik işlemlerinin ardından otizmli oğrencilerin geometrik şekillere ilişkin bilgilerini ölçmede geçerli ve güvenilir biçimde kullanılabilecek bir ölçme aracı olduğunu ortaya koymuş olup oluşturulabilecek hipotezlerin doğru bir şekilde test edileceği görülmüştür.

1-) Uygulanacak fiziksel aktivite ve spor egzersizleri, otizmli çocukların fiziksel ve zihinsel gelişimlerine etkileri araştırılabilir.

2-) Otizmli çocuklar üzerine yapılan bilimsel çalışmalar arttırılmalıdır.

3-) Otizm ve video model üzerine yapılan bilimsel araştırmalarda daha çok denek sayısı kullanılarak incelemeler yapılabilir.

4-) Bilgisayarlı öğretim dersleri arttırılarak geometrik figürlerin tanıtılması sağlanabilir.

\section{Kaynaklar}

Üstüner Top, Güleç-Aslan ve ark.(2009) Otistik Çocuğa Sahip Ailelerin Yaşadıkları Sorunlar ile Ruhsal Durumlarının Değerlendirilmesi: Niteliksel Araştırma Fadime * Çocuk Dergisi 9 (1):34-42

Güleç-Aslan Y, Kırcaali-İftar G, Uzuner Y. (2009) Otistik Çocuklar İçin Davranışsal Eğitim Programı (OÇİDEP) Ev Uygulamasının Bir Çocukla İncelenmesi, Ankara Üniversitesi Eğitim Bilimleri Fakültesi Özel Eğitim Dergisi. 10 (1) $1-25$

Yıldırım, S., Akman, B.\& Alabay, E. (2012). Okul öncesi dönem çocuklarına sunulan Montessori ve mandala eğitiminin görsel algılama davranışlarına etkisinin incelenmesi. Buca Eğitim Fakültesi Dergisi, 32, 92- 103.

Güven, D., Vuran, S. (2015). Otizm spekturum bozukluğu olan bireylerin sosyal becerilerinin geliştirilmesinde grup müdahaleleri. Ankara Üniversitesi Eğitim Bilimleri Fakültesi Özel Eğitim Dergisi, 16(1), 29-51.

Güneş, F. Otizm ve Otistik Çocukların Eğitimi, İlya Yayınları (2013).

Gürsel, O. (1993). Zihinsel engelli çocukların doğal sayıları, gerçek nesneleri kullanarak eşleme, resimleri işaret ederek gösterme, rakamlar gösterildiğinde söyleme becerilerinin gerçekleştirilmesinde bireyselleştirilmiş öğretim materyalinin basamaklandırılmış yöntemle sunulmasının etkililiği. Eskişehir: Anadolu Üniversitesi Yayınları

Gülsöz, T., Çıkılı, Y. (2018). Otizm spektrum bozukluğu olan öğrencilere soğuk içecek hazırlama ve sunma becerisinin video model ile öğretimin etkililiği. Abant İzzet Baysal Üniversitesi Eğitim Fakültesi Dergisi, 18 (1), 210-229.

Girli, A. (2004). Rep-R ölçeği ile değerlendirilen ve TEACCH programı uygulanarak eğitilen iki otistik çocuğun gelişimlerinin incelenmesi. Gelişimsel Nöropsikiyatri Toplantıları: Uluslararası II. İstanbul Otizm Sempozyumu.

Berkmen, H.2009, Kuantum Bilgeliği ve Tasavvuf, Sistem Yayınc1lık, No:622, 2.Baskı, İstanbul.

Büyüköztürk. Ş. (2002). Faktör analizi: Temel kavramlar ve ölçek geliştirmede kullanımı. Eğitim Yönetimi Dergisi, $32,470-483$. 


\section{Avrupa Bilim ve Teknoloji Dergisi}

Özyürek, M. (1990). Özel eğitimde teşhis sorunları ve öneriler. Eğitim Bilimleri Birinci Ulusal Kongresi. Ankara: Ankara Üniversitesi Eğitim Bilimleri Fakültesi Yayınları.

Köymen, Ü. (1994). Öğrenme ve Ders Çalışma Stratejileri Envanteri: Geçerlik ve Güvenirlik Çalışması. Psikolojik Danışma ve Rehberlik Dergisi, 2(1), 19-28.

Tekin, H. (1993). Eğitimde Ölçme ve Değerlendirme. Ankara: Yarg1.

Tezbaşaran, A.A. (1996). Likert tipi ölçek geliştirme kılavuzu. Ankara: TPD Yayınları.

Turgut, M.F. (1997). Eğitimde Ölçme ve Değerlendirme Metotları. Ankara: Gül Yayınevi.

Yıldırım, C. (1999). Eğitimde Ölçme ve Değerlendirme. Ankara: ÖSYM yayınları.

Tavşancıl, E. (2010). Tutumların Ölçülmesi ve SPSS ile Veri Analizi. Ankara: Nobel Yayın Dağıtım.

Semerci, Ç. (2004). Ilköğretim Türkçe ve Matematik Ders Kitaplarini Genel Değerlendirme Ölçeği, C.Ü. Sosyal Bilimler Dergisi Mayıs 2004 Cilt : 28 No:1 49-54

Otrar, M., Argın, F.S (2015). Öğrencilerin Sosyal Medyaya İlişkin Tutumlarını Belirlemeye Yönelik Bir Ölçek Geliştirme Çalışması, Eğitim ve Öğretim Araştırmaları Dergisi, Cilt:4, Sayı:1 Makale No:37.

Otrar, M., Çağırgan Gülten, D., Özkan, E. (2012). İlköğretim Öğrencilerine Yönelik Öğrenme Stilleri Ölçeği Geliştirilmesi, Eğitim ve Öğretim Araştırmaları Dergisi, Cilt:1, Sayı:2 